\title{
Higher Education as a Gift and as a Commons
}

\author{
Andreas Wittel \\ Nottingham Trent University, Nottingham, UK, andreas.wittel@gmail.com, \\ https://www.ntu.ac.uk/staff-profiles/arts-humanities/andreas-wittel
}

\begin{abstract}
This paper takes as a starting point Lewis Hyde's (2007, xvi) assertion that art is a gift and not a commodity: 'Works of art exist simultaneously in two 'economies', a market economy and a gift economy. Only one of these is essential, however: a work of art can survive without a market, but where there is no gift there is no art." I want to argue that the same claim should be made for those aspects of academic labour that refer to teaching and education. Education can survive without a market, but where there is no gift there is no education. However the gift that is part of all educational processes gets rather obscured in regimes where higher education is either a public good or a private good. In regimes of higher education as public good the gift gets obscured by the provision of a service by the state. In regimes of higher education as a private good (e.g. higher education in the UK) the gift gets even more obscured, obviously so. It is only in a third educational regime, where education is a common good (e.g. the recent rise of the free universities), that the gift character of education can properly shine. Whilst this should be celebrated, the notion of a higher education commons poses some severe challenges. The paper ends with an examination of possibilities of academic activists to rescue or even strengthen the gift-like character of education.
\end{abstract}

Keywords: Academic Labour, Higher Education, Political Economy, Gift, Commons, Labour, Alienation

\section{Introduction}

The world of work has lost its magic. It has become an increasingly dystopian place, causing unhappiness, stress, anxieties and mental illnesses among workers. Prominent sociologists such as Pierre Bourdieu (1999), Richard Sennett (1998) and André Gorz (1999) provide early accounts for such a development. Sennett is interested in the new work regimes of neoliberal capitalism and their social consequences. He describes how workers find it increasingly hard to generate meaning and identity under the conditions of a work ethic that worships change and risk and condemns routine, that equates resistance to change with failure. Lasting and trustful relationships at work and outside work are increasingly hard to maintain, loyalty to the organisation loses its value. Skill, craft, and the accumulation of experience count less than a flexible mindset that knows how to react to change and walk away from disaster. "The trick is, let nothing stick to you" (Sennett 1998, 79). The social results of these developments are fragmentation and the weakening of bonds. Trust becomes replaced with quality control and various forms of bureaucratic protocols that are supposed to secure good practice.

André Gorz describes a similar change. While work in Fordism, with all its obvious faults, had at least contributed to social cohesion and social integration, while it had given all workers a sense of usefulness and entitlement, work in post-Fordism is far more destructive for both, society at large and the individual worker.

"Fear and tremble [...] Never mind what you are paid, so long as you have a job [...] Be prepared to make any and every concession, to suffer humiliation or subjugation, 
to face competition and betrayal to get or keep a job, since those who lose their jobs lose everything" (Gorz 1999, 56).

More recently Carl Cederström and Peter Fleming (2012) confirm Gorz's account. "Dead man working" is a bleak analysis of work in a period where capitalism has failed as a political economy but succeeded to colonise life itself. Very much in line with concepts of the Italian post-operaismo school, Cederström and Fleming describe the contemporary struggles not as a battle between capital and labour, but as a struggle between capital and life. The attack of capital on life creates among workers in a wide range of occupations and hierarchical levels a feeling of non-living which affects even our dreams and destroys our sleep.

"Whether in the office, the call center, the service counter, in the creative industries, the retail show-floor or the backroom warehouse, life seems to be far away. We have always known that capitalism accumulates numerical value by subtracting social value, experienced as alienation, disenchantment, and dehumanisation. But what has now become evident is the sheer pointlessness of our daily endeavours" (Cederström and Fleming 2012, 2).

Contemporary accounts of work are very dark indeed. David Graeber (2015) observes a stark rise of "bullshit jobs" and hyper-destructive levels of bureaucratic managerialism. Barbara Czarniawska (2008) conceptualises humiliation as a "standard organizational product”. Yiannis Gabriel (2012) develops a concept of organisational miasma which describes a contagious state of material, psychological and spiritual pollution in organisations that undergo sudden and traumatic transformations, a state that has dehumanising effects on all those who are part of the organisation.

While the work of academics has always been commodified as wage labour, for a long time it had not been normal work in capitalist societies in the sense that it was not perceived to be alienated work as defined by Marx (1959). In contrast to other areas of wage-based labour academics had significant control of both, the products of their labour power (education and research) and the organisation of their work routines. It was work that was highly autonomous and academics had a sense of ownership of the products of their labour. ${ }^{1}$ With the marketization of higher education and the consequent restructuring of the public university to a corporate entity the work of academics has turned into academic labour and academics became exposed to the same experiences of alienation and dehumanisation as the rest of the workforce in capitalist societies. They also became exposed to a lethal combination of digital technologies and managerial forms of bureaucratisation that not only turned values into economic value, but worse than that, turned many qualities of academic work into measureable quantities, into endless segments of de-contextualised data. ${ }^{2}$

What was once academic work is now academic labour. I do not know the origins and the history of the term, but it is obvious that it became prominent with the transformation

\footnotetext{
${ }^{1}$ Alienation is both an objective and a subjective condition. It is difficult to come up with irrefutable empirical evidence for the subjective aspects of this claim. I have not found any relevant literature from, say, the 1950 s to the 1980 s, confirming that academic work at that time was largely non-alienated. But I have also not found literature in this period claiming the opposite. Therefore, I see the lack of academic literature in this period writing about academic work and alienation as an indication, that alienation in academia was not a great concern. It has only become a concern over the last two decades.

${ }^{2}$ My observation that academic labour is now as alienated as all other labour is not meant to be understood as a defence or a romanticisation of the public university. In fact the whole point of this article is an attempt to look beyond higher education in the regime of the public university.
} 
of the public university into a corporate institution. It is no coincidence that 'Workplace: A Journal for Academic Labor', which has critically analysed and documented this transformation, published its first issue in the year 2000. Academic labour describes academic work in the capitalist university.

There is little disagreement in the literature that the transformation of the public university into a corporate institution and the transformation of academic work into academic labour is not a development to be applauded - neither for academics nor for students. The many downsides of this process are all too clear, starting with the obvious fact that students begin their adult life with the burden of a huge amount of debt which they will have to repay for years and decades to come. They have to indebt themselves so they are able to compete in a job market that is shrinking enormously due to digital technologies and automation (Brynjolfsson and McAfee 2011; Ford 2016). Perhaps the most problematic effect is the integration of education into consumer culture and transformation of an educational interaction into a service industry where students are turned into customers and teachers into facilitators. While it is impossible here to go into great detail reviewing literature that critically explores this transformation I would like to recommend in particular the books by Sheila Slaughter and Gary Rhoades (2004), Chris Newfield (2008), Andrew McGettigan (2013) and Ruth Barcan (2016) on the commodification of higher education. Marilyn Strathern (2000), David Harvie (2006), Massimo De Angelis (2007), Silvia Federici and George Caffentzis (2007), Massimo De Angelis and David Harvie (2009), Mark Fisher (2009), Morgan Adamson (2009), the edufactory collective (2009), Ros Gill (2009), Nick Couldry and Angela McRobbie (2010), and Richard Hall (2013) explore the rise of measurements and quantification, the loss of autonomy, the intensification of work and its implications for academic labourers and the educational process. Contributions in Karen Gregory's and Joss Winn's (2016) special issue study the notion of academic labour from a Marxian political economy. Last, but not least, I recommend two articles of my friends and former colleagues Eeva Berglund (2008) and Liz Morrish (2017) who have explained their decision to turn their back on academia in sad but highly insightful accounts on the objective conditions and their subjective implications of academic labourers.

This article is not a critique of academic labour. If anything it could be read as a response to this debate. It is a response that firstly ignores all aspects of academic labour that are about research and about administrative work. It focuses merely on the educational aspects of academic labour. Secondly, it does not engage with the alienating and dehumanising aspects of labour in the corporate university. Instead it looks in the opposite direction, in what I call the gift in higher education. Even in the most alienating conditions of academic labour, higher education, if it still wants to be meaningful in any way, has to be an interaction that is about gift-giving. The purpose of this contribution is to highlight an aspect of academic labour that is easy to be overlooked in the age of the capitalist university: the gift in higher education. Clearly the gift in higher education is fading. It is under attack. At the same time it is the most essential part in the interaction between teacher and student. This is one of the contradictions of the neoliberal university. We teachers are trying to defend and rescue something against all odds. Even worse, we are trying to rescue something that is being captured by capital. I am rather doubtful that the gift can be protected or even strengthened in a political economy that turns education into a commodity. Then again, what is the alternative? In my view as an academic activist a search for alternatives is the order of the day. 
This contribution explores higher education as both, a gift and a commons. The part of the gift is largely conceptual. While this part touches on some pedagogical issues, the main focus is on the political economy of gift-giving in the educational process. I have no intention to contrast the rather dystopian accounts of academic labour with a story of hope. As already indicated, the gift in higher education is in danger of being obscured in the corporate university. But a gift there is nevertheless, a gift there has to be. This raises the question: which political economy of higher education can protect or even foster the gift in higher education? While higher education as a public good clearly provides a more fertile ground for the gift than its form as a commodity, I will argue that it is the political economy of the commons that brings out the gift most clearly. However, it is not clear what higher education as a commons would look like. After all, we do not have an elaborated history of a higher education commons. Therefore, the part on higher education as a commons is largely an exercise in utopian thinking. I will analyse recent initiatives in higher education that neither belong to the public university nor to the corporate university and inspect whether they could be conceptualised as a higher education commons.

\section{The Gift}

Lewis Hyde (2007) develops an interesting and innovative approach to gift theory. He explores the gift from the perspective of art. Hyde understands art as a gift. He explains the connection between gift and art through a comparison of art with non-art.

Using the example of Silhouette Romances, a specific line of romantic novels that are mass-produced "according to a formula developed through market research" (Hyde 2007, xv), Hyde explains their form of mass production. An agency uses surveys to decide on things such as the name of the heroine, her marital status, and the appropriate time for the hero and the heroine to get together sexually. Each book in this series has exactly the same amount of pages. Six new titles appear every month and are then sold at drugstores and various other locations. This series of romantic novels, so Hyde argues, is not perceived as art as it has been written with one intention only: for it to be sold on the market.

"It is the assumption of this book that a work of art is a gift, not a commodity. Or, to state the modern case with more precision, that works of art exist simultaneously in two 'economies', a market economy and a gift economy. Only one of these is essential, however: a work of art can survive without a market, but where there is no gift there is no art" (lbid., xvi).

For Hyde the notion of the gift refers on the one hand to the creation of the art work, to the gift or talent of the artist. But it also refers to an audience, to those who get challenged, touched, moved, inspired, or transformed by a work of art.

"A gift that cannot be given away ceases to be a gift. The spirit of a gift is kept alive by its constant donation. If this is the case, then the gift of the inner world must be accepted as gifts in the outer world if they are to obtain their vitality. Where gifts have no public currency, therefore, where the gift as a form of property is neither recognised nor honored, our inner gifts will find themselves excluded from the very commerce which is their nourishment. Or, to say the same thing from a different angle, where commerce is exclusively a traffic in merchandise, the gifted cannot enter into the giveand-take that ensures the livelihood of their spirit" (Ibid., xix).

The inner world of the gift is the inner world of the artist, the creator of the gift. The outer world refers to the recipients of the gift. While most anthropologists, starting with Marcel Mauss (1954), explore the gift from the perspective of social relations, Hyde has his starting point with the gift as an object. From this perspective of the gift as 
object he then explores its social dimensions. These social dimensions, Hyde insists, are not just the bond between the gift giver and its receiver. Ultimately they are about a community of people who circulate gifts.

The literature on the gift is long and rich. Particularly important is the work of Mauss (1954), Marshall Sahlins (1974), Annette Weiner (1992), Jacques Derrida (1994), Pierre Bourdieu (1997), Maurice Godelier (1999), Charles Eisenstein (2011) and David Graeber (2011). Concepts of the gift have been developed most of all in anthropology but also in other disciplines. I will ignore much of this huge body of work here as Hyde's approach to the gift is sufficient for the argument I am going to make later in this article.

There is much to praise about Hyde's work. In particular, I appreciate his interest in the immaterial aspects of the gift. A painting in a gallery exists obviously in a very material form, often with a frame that marks its physical space. However the gift of this painting does not travel in its material form, as the painting does not leave the gallery. The gift that the visitor of this gallery receives by being drawn to the painting is completely immaterial: a thought, a feeling, an experience, an understanding, a memory, a connection, or a vision. What the visitor of the gallery takes away will be in her body and her mind.

For Hyde the cardinal difference between gift exchange and commodity exchange is the fact that a gift establishes a bond between two people, whereas the commodity does not. The commodity might have value (in the sense of exchange value), but the gift has worth. "We do not deal in commodities when we wish to initiate or preserve ties of affection" (Hyde 2007, 85). For this reason we associate the gift with community and with obligation, whereas we associate commodities with alienation and freedom. The bond creating nature of the gift is also the reason why some gifts must be refused.

Perhaps the most important point Hyde makes about gifts is their tendency to circulate. He uses various examples to illustrate their circulation in gift communities. Scientific knowledge blossoms much more in a gift environment compared to a market environment that treats scientific knowledge as a commodity. This is also true for material gifts. They are often passed on to others. They leave the binary of give and take and travel from one person to the next. The gift increases its worth as it moves from the second to the third person. "While gifts are marked by motion and momentum at the level of the individual, gift exchange at the level of the group offers equilibrium and coherence, a kind of anarchist stability" (Hyde 2007, 97). Indeed, Hyde sees strong connections between anarchist theory and practices of gift exchange. Ultimately he understands gifts as an "anarchist property" (Ibid., 120) in that both, gift exchange and anarchism share the assumption that community appears at its best, when part of the self is not restrained but given away.

While Hyde agrees much with Mauss, the godfather of gift theory, that every gift calls for a return of the gift, his concept of "gift circulation" and the "gift community" opens up a narrow reading of reciprocity, a form of generalised reciprocity, to use a concept by Mauss. Someone in an art gallery who receives a gift will find it hard to return this gift to the artist. Instead he or she will pass on the gift in his/her community. The gift of scientific knowledge works in a similar non-binary way. The gift is returned in that it is spread or even enriched.

It is obvious where I am going with this. I want to ask if (higher) education is also a gift, similar to art. Before exploring this question in more detail, I want to share a personal experience that can be considered as an example of an educational gift. 


\section{Mayerhöfle}

I received the most important part of my academic education in a pub. I received this education in a non-university location, outside formal teaching times, and outside formal university structures. I received it in a location that is commonly associated with leisure and pleasure. I studied Empirische Kulturwissenschaft (cultural studies) in Tübingen, South-West Germany, in the 1980s and early 1990s. Having completed the BA degree, it took me four years to hand in my MA thesis and another four years to finish the doctoral dissertation. Long before I enrolled as a student, the academic staff at Cultural Studies in Tübingen had created something (a practice, a routine, a ritual, an institution) that is still ongoing. In fact these practices still exist, across cities, universities, faculties, and departments. Every Thursday late afternoon they organised a two-hour colloquium for all postgraduate students (MA students and PhD students). After the colloquium we went to the 'Mayerhöfle', a pub in the city centre not far from the School, where Mrs. Mayer kept a back room reserved for us. We always arrived at $8 \mathrm{pm}$, right after the colloquium and we were often the last ones to leave. Usually we were kicked out by Mrs. Mayer around 1am.

I had eight years of education in this pub. While I don't want to minimise the significance of the more formal education structures at the School, the informal education in the 'Mayerhöfle' on Thursday nights stands out as it was here that we postgrad students learned to properly work through the topics and ideas that were introduced to us in the colloquium. Thematically the pub visit was an extension of the colloquium, yet it had its own rules and conventions. It generated a very specific learning experience. In terms of debate and contributions the colloquium was very much dominated by our teachers. We students were often too inhibited to join the discussion. This changed in the pub. Here we students found our voice, challenging each other and our teachers. The hierarchies between teachers and students, so visible in the colloquium, became more clouded in the smoke of cigarettes and heated debates. Alcohol surely helped and so did the physical proximity in the back room. While the colloquium was interesting it was still considered to be work and duty. Learning in the colloquium was social, learning in the pub was sociable. It was joy and lust and play and life.

However, this should not be read as an idyllic portrayal of this space. It was not always joyful of course. At times it was dark and sad. Often it was overly competitive and argumentative. We students were fighting for status and for the attention of our teachers. It should also be emphasised that our teacher's out-of-contract time was not evenly distributed across all faculty. Gender played a stratifying role here. Furthermore the risks involved in developing these bonds were not evenly shared across race and gender lines. Clearly it was not paradise. But it was always meaningful. It was always connected to our desires.

Taking into account all our fears, our critical recognition of struggles for status, our awareness when we humiliated and embarrassed ourselves, we kept participating. We did not perceive this interaction as learning or being taught. This is what I did not understand at the time: our learning just happened anyway. It happened nearly unintentionally. We learned without being much aware that this was education too, just a different one.

Our teachers gave us a gift. We were given their time - their out-of-contract time. Obviously they did not get paid to spend every Thursday night with us students in the pub. Furthermore, we were given another space for learning and educational interaction. We were given a more joyful way to understand the themes of the curriculum, Freud, Marx, the Frankfurt School and French post-structuralism. We were given an appreciation for detail, thought, abstraction, and critique. 
All this is amazing in itself, but we received even more. We were given the opportunity to bond with our teachers and to take this bonding beyond the level of ideas. We bonded in various ways, not just intellectually but also emotionally. We were welcomed into the academic community of our School. In the 'Mayerhöfle' we postgrad students also bonded with each other. Many of these ties, both between us students and between us and our teachers have turned into ties for life. Without this gift from our teachers our bonds would not have been as deep and intense, they would not have lasted the way they did over time. With their time, their attention, their availability and their interaction, our teachers provided care. They created a gift-community which talked about values, ethics and politics, and which exchanged information, ideas, reflections and emotions. I doubt that I would have become an academic had I not received this gift. My teachers' gift had a profound impact on who I have become.

\section{Higher Education as a Gift}

The above example is perhaps a bit unusual in the British context and rather extreme in the context of the corporate university. What makes it unusual is the fact that the gift comes in the form of a change of the environment for education. This might obscure the more mundane aspects of the gift that are about education itself - not about the settings in which education takes place but about the content of teaching. It is these mundane aspects of education that are crucial for an understanding of its gift-like character.

This is the key argument I want to make: Higher education is a gift and not a commodity, just as art is a gift and not a commodity in Hyde's concept. Or, to be more specific and situate higher education in the edu-factories of digital capitalism: Education can exist in two economies, in a market economy and in a gift economy. However, only one of these is essential. Education can survive without a market, but where there is no gift there is no education. The gift in education is something that lies beyond economic rationality: it refers to a specific form of pedagogy. Similar to art, the gift in education refers to a gifted teacher and to a student who becomes enriched, inspired, challenged, moved, or transformed. The gift in education lies in the experience of the interaction between teacher and student. This gift can only emerge if the interaction is dialogical and mutual, if there is resonance.

Indeed, Hyde briefly refers to "teachings" as a gift, using the example of Alcoholics Anonymous (AA) rather than schoolbook lessons. These teachings are transformational gifts and they need time. The transformation is slow. It may take years before an insight has sunk in so deeply that its recipient can pass it along. Hyde writes:

The program itself is free. AA probably wouldn't be as effective $[\ldots]$ if the program was delivered through $[\ldots]$ the market $[. .$.$] because the spirit behind them would be differ-$ ent (the voluntary aspect of getting sober would be obscured, there would be more opportunity for manipulation, and $[\ldots]$ the charging of fees for service tends to cut off the motivating force of gratitude (Hyde 2007, 57-58).

Let's inspect closer the educational gift that emerges in the interaction between student and teacher. For this I will introduce Hartmut Rosa's concept of resonance. German sociologist Rosa (2013) analyses contemporary social transformations mainly through the lens of acceleration. Rosa identifies three forms of acceleration that have changed 
the speed of modern life. The first one, technological acceleration, refers to transport technologies, communication technologies, and technologies of production. The second form is acceleration of social change, which refers to things such as cultural knowledge, social institutions, and personal relationships. The third form is the acceleration in the pace of life and a chronic lack of time: even though technological change should free up time for individuals (as we can travel, communicate and produce at ever increasing speed), our pace of life is still accelerating. These three forms and their internal connection is what Rosa calls "social acceleration". The discrepancy between technological acceleration and organisation efficiency and the acceleration of our pace of life is what Rosa defines as growth: "the average rate of growth (defined as increase of the total quantity of things produced, communicated, distances covered, etc.) exceeds the average rate of acceleration" (Ibid., 68-69). Or, a bit simplified: The more we try to save time via technological means the less time we have. However this does not mean that technological innovations are the culprit. These innovations do not make our life faster. They are rather a consequence of an experience of scarcity of time. The real culprit is capitalism, a system that turns time into money and acceleration into profit. In the logic of capital, social acceleration turns into an unavoidable compulsion.

From this perspective Rosa develops a new critique of alienation. If changes in the pace of our life occur at an ever faster rate, it becomes difficult to maintain strong feelings, convictions, and connections, social, institutional, personal, and intimate connections. What is required instead is flexibility and adaptability to change. There is no need for depth and authenticity any more. All attempts to intimately familiarise ourselves with the status quo, all attempts to create stability stand in direct contrast to the need to keep up with change. Rosa understands alienation as a loss of autonomy and self-determination, as an experience of life under the condition of frenetic acceleration. Such a concept of alienation is not based on Marx, on exploitation and injustice. It relates more to concepts of alienation developed by Frankfurt School theorists, to an instrumentalist approach towards nature (e.g. Horkheimer and Adorno in Dialectics of Enlightenment), or to a consumerist ideology (e.g. Marcuse in One-Dimensional Man). It is about a certain mode of being, about our relationships with the world, with nature, and with each other.

For Rosa (2016) the opposite of alienation is resonance. We are non-alienated when we manage to build non-instrumental, responsive, and transformative relationships. These are relationships with people, but also with nature and with art. They are not about domination, manipulation and control. Instead they are about a form of interaction that is based on mutuality, on the dialogical nature of listening and answering. Relationships resonate, when our interactions are important and meaningful, when we are touched and affected by them. We travel to the sea because the sea can speak to us, because we become transformed by our interaction with the sea. We listen to a live concert because we want to be affected and transformed by this experience. Resonance, Rosa insists, does not mean a harmonious relationship. Complete harmony does not generate dialogue and resonance. Resonance is as much about dissonance, about discerning difference. Thus disagreement, even conflict, is one important ingredient of resonance. But resonance also needs convergence and the building of bridges. Otherwise, transformation would be impossible.

It is fascinating how well it resonates with Hyde's take of the gift. So how can we understand higher education through the lenses of resonance and gift giving? Obviously higher education depends on the principles of interaction, dialogue, mutuality, and reciprocity. It cannot be a one-way street. Concepts of the "pure gift" (Derrida 1994), a gift that is based on altruism, do not apply here. The pure or altruistic gift does 
not create social obligations, thus does not produce any bonds. It does not produce resonance. In this respect the pure or altruistic gift is ironically rather close to monetary transactions. I am not arguing against the notion of a pure gift per se (we can see it for example in anonymous donations such as money, objects, blood, organs etc.), but in the context of higher education the notion of the pure gift does not make any sense. For this reason the pure altruistic gift is not so much about everyday life, but confined to acts of emergency, e.g. donations (blood, organs, money). The concept of education as a gift is deeply embedded in anthropological perspectives, it is about mutuality and the social. For higher education to work as a gift it has to generate feedback. No response, no resonance, no gift.

It is this insistence on resonance and the social or mutual character of gift-giving which helps to avoid a romantic portrait of higher education as gift, to avoid the rather naïve misperception that higher education always is a gift, period. It is only a gift if it is successful, if it creates resonance. A visitor of an art gallery who remains unaffected by a work of art in front of her will hardly perceive this work as a gift. The same is true in education. Students who remain unaffected by the interaction with their teacher do not receive a gift. This simple observation invites further reflections on three things, (1) on the affective nature of academic labour, (2) on the scope of non-resonance in educational relationships between teachers and students, and (3) on the political-economic understanding for such unsuccessful or non-resonant gifts.

The first point to make is that academic labour - both as research labour and educational labour - is always what Hardt and Negri $(2000 ; 2004)$ define as affective labour. For them affective labour is one dimension of immaterial labour. Immaterial labour is labour that produces immaterial outcomes such ideas, concepts, knowledge, emotions and affects. Affective labour is labour that produces or modifies emotional or affective experiences in people.

"Unlike emotions, which are mental phenomena, affects refer equally to body and mind. In fact, affects, such as joy and sadness, reveal the present state of life in the entire organism, expressing a certain state of the body along with a certain mode of thinking. Affective labor, then, is labor that produces or manipulates affects [...] One can recognise affective labor, for example, in the work of legal assistants, flight attendants, and fast food workers (service with a smile). One indication of the rising importance of affective labor, at least in the dominant countries, is the tendency for employers to highlight education, attitude, character, and 'prosocial' behaviour as the primary skills employees need" (Hardt and Negri 2004, 108).

While Hardt and Negri argue convincingly that affective labour has become increasingly important for post-industrial societies in cognitive capitalism, the affective labour of the teacher is not a recent phenomenon. Teaching is never merely about the dissemination of content, but as much about pedagogy and didactics, about methods to deliver the taught content in a way that creates resonance. The relationship between a teacher and a student is as much an affective relationship as it is an intellectual relationship. The teacher fails with the delivery of the content if the student does not become affected. Something about teaching and affective labour has changed nonetheless. The last phrase in the quote by Hardt and Negri highlights the fact that affective labour is being exploited by capital. The more education ceases to be a public good and gets transformed into a commodity, the more the exploitation of affective labour matters, as its implications are devastating for the survival of the gift.

This brings us to the second point, to the scope of failed forms of gift-giving in higher education. It goes without saying that not every interaction between teachers and stu- 
dent produces resonance. In fact a large part of educational interactions could be described as non-resonant, as either teachers to not succeed in their attempts to hand a gift to students (e.g. they don't get the attention of students) or as students do not get affected, no matter how hard the teachers tries.

It is obviously impossible to find any empirical evidence for these unsuccessful forms of gift-giving in higher education. It is impossible to measure them in any meaningful way. As often, qualities of interactional processes resist quantification. Nonetheless, hardly anybody who teaches in higher education would dispute that often, in fact way too often, the attempt to resonate falls short of expectations. To put it bluntly, in the corporate university of "communicative capitalism" (Dean 2014) the notion of resonance in student-teacher-interactions might more often be the exception than the rule.

The third and last point raised by the observation that resonance in (higher) education is an objective and not something that can be taken for granted refers to the political economy. How can we think about the gift as a specific form of exchange with different forms of property regimes and different forms of governance? This is a point about the dual nature of education in the marketplace, about education that is simultaneously a gift and a commodity. With respect to resonance and gift-giving, can we compare education as a public good with education as a commodity? Is there overall less resonance when higher education has to be paid for? Does the gift get more obscured in a political economy where higher education has joined the market?

Indeed, the status and the nature of the gift in education changes according to the political-economic regime, in which higher education is provided. To be more precise, these political-economic regimes refer to different forms of property, to public property and private property. In both regimes, the public university and the commodified university the gift is obscured. In regimes of education as a public good (the public university) the gift gets obscured by the provision of a service by the state, a provision that is free for students and paid for by taxes.

In regimes of education as a private good (the commodified university) the gift gets even more obscured, obviously so. We usually don't perceive something to be a gift that we pay for. Considering that fees in higher education are not small change but lifechanging investments (and debts) it is no wonder that students demand and expect a good return for their investment. What happens when students are turned into consumers of education? Media theorist Bernard Stiegler (2010) has originated a radical critique of the ideology of consumerism. For Stiegler consumerism produces impoverished and passive subjects, it leads to a destruction of "savoir vivre with the aim of creating available purchasing power" $(2010,27)$. He describes consumerism as a form of proletarianisation. While he does not connect his critique of consumerism to the field of education, such a link is rather illuminating. Students who define themselves as consumers of education, become impoverished, as all positive aspects of learning (and the work, dedication, commitment and energy that is required to learn) are being overshadowed by an ideology that equates the purchase of education with the ownership of knowledge. After all, consumption is the opposite of production and work. The implications for teachers in the regime of commodified education have already been outlined in the first part of this article. It is safe to say that the market intensifies experiences of alienation for both, the teacher and the student. Ultimately the market will suffocate the gift-giving nature of education.

However, this does not mean that a return to the public university is the most desirable option. Nostalgia for education as a public good tends to ignore the severe critique that this regime has generated. Nearly half a century ago Pierre Bourdieu (1986) argued convincingly that class and social distinctions are predominantly upheld through 
education and higher education. Paul Willis (1977) and Randall Collins (1979) have developed similar arguments about university education as a space of privilege. For this reason, I have sympathy with the position of the edu-factory collective, which states the following:

The state university is in ruins, the mass university is in ruins, and the university as a privileged place of national culture - just like the concept of national culture itself - is in ruins. We're not suffering from nostalgia. Quite the contrary, we vindicate the university's destruction $(2009,1)$.

It is only in a third regime, in the political economy of the commons that the gift in higher education could truly shine. Obviously this does not mean that every higher education commons is per se an idyllic site. Issue of power and domination will not go away. But the common ownership of higher education does provide the most fertile ground for the gift to unfold. The last part of this article is concerned with a review of recent initiatives which might belong to a commons-based regime of higher education. It is also an exercise in utopian thinking.

\section{Higher Education as a Commons?}

A commons is usually described in political economy as a set of natural or cultural resources that can be used by all those members who are part of a commons. The members of a commons are stakeholders with an equal interest in the resources that are being shared. These resources are not privately-owned, they are owned and shared by the community of commoners. The resources are either created or administered by the commoners. They can be such different things such as land, air, water, language, knowledge, music or software. The big enemy of the commons is the market, and indeed capital. Processes of privatisation, marketization, and commodification of common property is called the enclosure of the commons.

Every commons consists of three elements: (1) people who share the commons (the commoners), (2) resources that are being shared, and (3) a form of self-organisation and normative framework that sets out how the common resources should be created, shared, maintained and developed further.

Underestimating this normative framework and the possibilities of establishing rules that are accepted by all commoners might have been the crucial weakness in Garrett Hardin's (1968) analysis of the tragedy of the commons. His arguments, which have been highly influential over several decades and which were used by neoliberal politicians to transform various commons into private property, are rooted in an assumedly unsolvable conflict between the individual interests of the commoners on the one hand and the interests of the commoning community on the other hand. For Hardin, the individual interests of the commoners tend to destroy the common good eventually. However, Hardin did not take into account that the commoners are able to communicate, establish normative frameworks and to manage possible conflicts over individual interests in a productive way.

Much of the political economy of Elinor Ostrom is dedicated to this issue. Her work, which received the Nobel prize for economics in 2009, inspects the governance of a great number of commons in the material world (land, air, water, etc.) that achieve sustainability and avoid destruction. Without getting into too much detail, Ostrom (1990) argues that a range of principles need to be in place for the commons to function 
properly. I want to mention two of these principles. Firstly, any commons in the material (natural) world has to establish a set of rules. Secondly, those who do not obey these rules have to be sanctioned by the community of commoners.

Over the last couple of decades, the commons has had an enormous revival. Surely this is a consequence of Ostrom's work, but it has also a lot do to do with the astonishing rise of the digital commons (Wittel 2013). The digital commons refers to "results of social production that are necessary for social interaction and further production, such as knowledges, languages, codes, information, affects, and so forth" (Hardt and Negri 2009, xiii). It refers to those areas of the Internet that are not built for the market. This is a new form of production, which Yochai Benkler (2006) calls variably "nonmarket production" or "social production" or "commons-based peer production". He has coined these terms to describe a new model of socio-economic production, in which large numbers of people work towards common goals without any financial compensation for those who contribute to the common good.

Massimo De Angelis (2017) makes an important distinction between endogenous and exogenous dimensions of the commons. While Ostrom is mostly concerned with the internal aspects of the commons, with the social system between commoners Marxian theorists are more interested how the social system of a commons is influenced by external factors, by capital. As will be shown this is an important distinction for an understanding of the higher education commons.

In order to explore the idea and the possibility of a higher education commons we need to start on a more basic level with the relation between education and a commons. The notion of an education commons is in itself rather problematic. If we stick to the definition above, the shared resources in an education commons would be a combination of knowledge and a form of pedagogy to gain more knowledge. However, contrary to the definition, these resources are not equally shared in a community of education commoners. In fact, they cannot be equally shared as the very process of education is fundamentally hierarchical with teachers more likely to be on the giving end (delivering knowledge and deciding on the form of pedagogy) and students more likely to be on the receiving end of the educational process. A similar problem arises with the self-organisation and the governance of an education commons. It is difficult to imagine a setting that gives students the same influence as teachers in the organisation and the normative framework in educational processes.

Still, there are numerous examples of education commons. For this we have to turn to anarchist and libertarian theories and practices of education (Suissa 2010). Most anarchist educators see an anarchist school as an embryo of a future anarchist society. Therefore, anarchist education has to embrace and reflect core anarchist values and principles such as equality, autonomy, brotherhood, solidarity, mutualism, non-coercion, generosity, and collective forms of decision-making. One of the key challenges for anarchist education is to translate these values and principles into the practicalities of the relationship between teachers and pupils. The challenge is to make this relationship as equal and non-hierarchical as possible. Therefore, famous anarchist schools such as the Escuela Moderna in Barcelona, the Ferrer School in New York, and the Walden Center in Berkeley have put their emphasis on a more spontaneous, childcentred and anti-authoritarian pedagogy, on learning-by-doing, on communal and cooperative learning. Pupils were included in decision-making processes about the curriculum and encouraged to organise their own work schedule. Rigid timetables were to be avoided, and pupils were allowed to come and go as they wished. Last, but not least, these schools insisted on a form of teaching that does not make use of grades, awards, and punishments. 
Having [...] started from the principle of solidarity and equality we are not prepared to create a new inequality. Hence in the Modern School there will be no rewards and no punishments; there will be no examinations to puff up some children with the flattering title of 'excellent', to give others the vulgar title of 'good', and to make others unhappy with a consciousness of incapacity and failure (Francisco Ferrer 1913; quoted in Suissa 2010, 79).

Another example for an education commons is the much younger tradition of homeschooling or home education communities. While homeschooling is as old as mankind, the modern homeschooling movement started in the 1960s as a reaction to state education. It is not an anarchist invention, but has received much support from anarchist educational philosophers such as Ivan Illich (1971) and John Holt (1976). More recently, however, it has been embraced by wealthy, conservative and sometimes farright groups, which is a good example to demonstrate that not every commons is per se inspired by egalitarian or even communist values. Homeschooling initiatives are a commons as they are neither organised by the market nor by the state. They are run by parent-commoners and function according to the time and labour they invest. All parents who are part of a homeschooling network (or community) invest more or less equally in such a project and have more or less equal influence in the governance of the network.

So far we can conclude that an education commons is generally a rather problematic concept due to the hierarchical relationships between teachers and students (pupils). Nevertheless we can find historical and contemporary examples of educational institutions that come very close to the political economy of a commons. What does this mean for higher education? Due to the highly specialised nature of higher education an arrangement similar to homeschooling is nearly impossible to set up.

In the last part of this article I will review two developments in higher education that are neither organised by the state nor by the market. Both developments are a response to the commodification of higher education and to the failure of the state to secure higher education as a public good. One of these developments are massive open online courses (MOOCs), or more precisely, free (as in free beer) MOOCs. The other development is the rise of Free Universities (here free stands for both, freedom and free beer).

\section{Free $M O O C s^{3}$}

Massive open online courses (MOOCs) are a child of developments in digital technologies and the social web. The first MOOCs emerged from the open-educational resources (OER) movement. They provide unlimited participation and open access via the internet. They usually consist of a mix of educational material (texts, videos, problem sets, filmed lectures) and interactive user forums. Some MOOCs, for example the University of the People (UoP), the Open Educational Resources University (OERu),

${ }^{3}$ As this article is about the gift and the commons, I will ignore those many MOOCs that are for profit and that have been built with venture capital. I will also avoid a more general discussion of MOOCs and focus specifically on issues related to the commons and the gift. For a more general critical discussion I refer to the work of James Grimmelmann (2014) and Jonathan Poritz and Jonathan Rees (2016). 
and more recently edX are non-profit organisations which provide a free education for students.

The reasons and motivations for the building of free MOOCs are complex. Most early MOOCs that came out of the Open Education movement such as the UoP were developed with the aim to widen university education with a clear focus on disadvantaged geographical areas. While this aim needs to applauded there is also legitimate criticism of a rather (post)colonial approach to bring education to Africa. But not all free MOOCs originate from a concern to fight inequality and foster development in disadvantaged areas. Some MOOCs, particularly those who are an extension of traditional universities, are ultimately promotional products for prestigious higher education institutions (Winn 2012).

Each of these institutions have slightly different arrangements and different business models, but there is also much common ground. They are all based on a fundamental distinction between learning and assessment. While the courses are free, a fee is required if students want certification.

This distinction between gratis learning and fees for assessments and certification is reflected in the educational labour that is necessary to provide for learning and for assessments. In non-profit MOOCs the educational labour that refers to teaching can be reduced to a minimum as students interact either with peers (in forums) or engage with educational resources. Thus educational labour is only needed to prepare the course and to assess students' coursework. Depending on the taught content and the design for feedback and assessment, educational labour can further be reduced through peer-reviewing and group collaboration on the one hand and automated feedback and machine grading on the other hand.

The advantages of MOOCs are undeniable. They provide an affordable alternative to university education. They also improve access to higher education, particularly in geographical regions where access to universities is difficult. For futurist Jeremy Rifkin (2014) MOOCs are the product of a radical overhaul of higher education. They deliver higher education at marginal costs. Therefore, MOOCs, so Rifkin's rather euphoric prognosis suggests, represent a transformation of higher education away from capitalist markets and toward a collaborative commons.

"The capitalist era enshrined a model of teaching designed to prepare students to be skilled industrial workers. The classroom was transformed into a microcosm of the factory. Students [...] were conditioned to follow commands, learn by repetition, and perform efficiently. The teacher was akin to a factory foreman, handing out standardized assignments that required set answers in a given time frame [...] The transition from the capitalist era to the Collaborative Age is altering the pedagogy of the classroom. The authoritarian, top-down model of instruction is beginning to give way to a more collaborative learning experience" (Rifkin 2014, 109-110).

Let's ignore for a moment the rather simplistic portrait of the traditional brick-andmortar university as a form of authoritarian and factory-like education and focus instead on his equation of MOOCs with the collaborative commons. While he is correct to point out that MOOCs have the potential to foster peer learning between students, this is not the full story. Rifkin neglects that a large part of learning in MOOCs is not collaborative but a rather lonely engagement with educational resources in the form of course material. Average completion rates for MOOC degree programmes are lower than $10 \%$, with most students dropping out in the first few weeks. The reasons for not finishing the degree vary, but a general unhappiness with traditional forms of content delivery through video lectures features rather high (Colman 2013). It is not the collaborative aspects of learning that causes students to drop out, but the lonely engagement with 
course material. Similarly the commons in MOOCs is a rather reduced commons, a commons between peer learners who can interact. It is not a commons that includes teachers, as their role is not very interactive. It lies mostly in the preparation of the course material and in the assessment of coursework.

This reduction of educational labour to pre-teaching (preparation of course material) and post-teaching (assessment of coursework) has profound implications for the notion of the gift. In these arrangements that rely on minimising interaction between students and teacher to achieve a near zero marginal cost education the gift is also minimal. After all, the whole point of MOOCs is self-directed learning. In this respect Rifkin's celebration of MOOCs' pedagogy as a stimulating, creative, collaborative and commons-based learning experience seems a bit naïve.

\section{Free and Autonomous Universities}

The second development in higher education is a rise in free and autonomous universities. This is unrelated to developments in digital technologies, it has a clear local and geographical set up. While free and autonomous universities have a long historical tradition, their recent surge is very much a response to the commodification of higher education. Free and autonomous universities are an activist approach to higher education that aims to create a non-alienated framework for teaching and learning. These institutions usually don't have formal recognition. Therefore, they are not in a position to offer certification comparable to public or private universities. Not that this is seen as a problem. On the contrary, it gives them a great amount of freedom with respect to both organisation structures and pedagogical approaches.

While organisational structures and pedagogical approaches vary between these institutions, there is a good deal of common ground. Most of them avoid or aim to reduce hierarchical structures between teachers and students. Most of them operate on the basis of collective decision-making processes. They also share much common ground with respect to pedagogy and the meaning of education. They reject a vision of university education that prepares students for work in capitalist economies. Instead they aim to transform higher education. They see education as a social and political project, as a crucial stepping stone for the creation of another society. Indeed, free and autonomous universities share most of the values of anarchist theories of education.

Over the last ten years free and autonomous universities have emerged in many geographical locations all over the world. An 'alternative education counter-cartography' lists more than 100 initiatives. ${ }^{4}$ Some of these initiatives are discussed in a reader on open education, edited by van Mourik Broekman et al. (2015).

It is hardly surprising that most of these initiatives are located in the strongholds of neoliberal capitalism, namely in the UK and the US. It is important to note that these initiatives are in different stages of development - some of them don't have a working IP address, some web sites have not been updated for a few years, some web sites are mere manifestations of protest against the corporate university, and some organise irregular public events. Indeed very few of these initiatives offer modules for students. In the UK, these are the Social Science Centre in Lincoln and the Manchester Social Science Centre. The Free University of Liverpool ran a module in $2011 / 12$ but not since then.

${ }^{4}$ https://www.google.com/maps/d/viewer?mid=1 NqScqpNo2fAa2AEAZ3cwaK7fuXw\& ll=52.06 2623365637364\%2C-1.8951416953125317\&z=8 
To understand why it is so difficult to develop sustainable institutions of autonomous higher education we need to turn our attention to labour. In stark contrast to the educational labour in MOOCs the labour of teachers who are involved in free and autonomous universities does not get reduced to assessing students work. In fact, as there is a lack of formal recognition and certification the emphasis on assessment is rather low. Educational labour here takes place predominantly in the interaction between teacher and student. While this educational labour clearly is voluntary and free labour, therefore a non-alienated form of labour, it is nonetheless intense and time-consuming. It requires a significant and sustainable enthusiasm from those who provide the educational labour. It is in these settings that the gift of higher education can shine especially bright and clear. However as this is a gift that does not generate an obligation to return the gift - similar as in art - it is fragile and vulnerable.

These free and autonomous universities are a higher education commons in the best sense. Unfortunately, they also reflect an aspect of the tragedy of the commons. However, this is a very different tragedy than the one outlined by Hardin. This is not about individuals who are part of an higher education commons and who are destroying it due to selfish behaviour. The tragedy of the higher education commons in the form of free and autonomous universities lies in the fact that these political economies are little islands that are surrounded by huge capitalist oceans. They are not destroyed from within. Tragically, they are difficult to sustain by voluntary educational labour in a capitalist world that produces an increasingly exhausted workforce. To argue with $\mathrm{De}$ Angelis (2017), it is not the internal social system between commoners that makes free universities so hard to sustain, but external forces such as capital. No matter how well free universities are organised as a common social system, they always have to deal with powerful forces of the external capitalist environment.

\section{Conclusion}

This article is an attempt to analyse higher education from a political economy perspective. It is a response to the academic labour debate, arguing with the work of Hyde and Rosa that higher education does not need the market economy, but does depend on a gift economy. If there is no gift there is no (higher) education, understood as a somehow transformative interaction. However, in the corporate university the gift is in danger of being obscured as the turn toward an educational consumer culture and the transformation of education as a service with student-customers and teacher-facilitators produces an environment that is dominated by a political economy of the market, where bonds between teachers and students become increasingly replaced by technologies of quality control, where qualities become replaced by measurement and quantification, where values become replaced by (economic) value. Needless to say, this is not a fertile ground for a gift economy.

To make matters worse, academic labourers who attempt to rescue the gift in higher education are confronted with the dilemma that the gift-giving interaction does not just benefit students - it takes place in an environment where all aspects of academic work (and life), including the affective relationships between teachers and students, are captured by capital. Ultimately the attempts by academic labourers to rescue the gift in education, which is what fundamentally defines our work, create an even higher level of exploitation. This is a story that is unlikely to have a good ending. For this reason I have explored the possibility of the gift in higher education in another political economy where education is neither a public good nor a commodity, but a common good. 
The result of this exploration does not provide much reason to be hopeful. While it is possible to organise education for pupils as a commons, for example via a homeschooling community of parent-commoners, such a model is impossible to replicate in the highly specialised area of higher education. Then again, new developments in higher education have recently emerged as a response to the corporate university. These initiatives are neither controlled by the state nor by the market, namely MOOCs and free and autonomous universities. Could they be conceptualised as a higher education commons?

MOOCs have an ambivalent relationship with a higher education commons. They are all about digital technologies and new forms of automation that reduce the amount of academic labour to a minimum. Therefore, there is not much of a gift in the educational process between teachers and students. However, they have the potential to create a higher education commons with respect to the community of students. They could be conceptualised as a form of commons-based peer learning. Whether this is a model of higher education that deserves to be taken seriously is beyond my judgement. However, the low percentage of completion rates does not suggest that this model will become hugely popular with students.

Free and autonomous universities are a much better fit for a higher education commons. In fact they are a perfect fit and they create a context where the gift in higher education can truly shine. This is a form of non-alienated academic work, as it is built on voluntary and non-paid labour. However, it requires a great deal of enthusiasm and a serious and time-intensive commitment from teachers. Herein lies the tragedy of the higher education commons. Free universities are sites for resistance and class struggle. They play an important role within social movements to educate for change. But they are little islands of true commoning in capitalist societies. They are unlikely to grow and pose a challenge to the model of the corporate university as it is difficult to turn them into a state of self-sustainability. For free universities to grow on a significant scale, a political economy of the commons has to emerge that goes well beyond the realm of higher education.

\section{References}

Adamson, Morgan. 2009. The Human Capital Strategy. ephemera: theory \& politics in organization 9 (4): 271-284. 19 January 2018. http://www.ephemerajournal.org/sites/default/files/9-4adamson.pdf

Barcan, Ruth. 2016. Academic Life and Labour in the New University: Hope and Other Choices. London: Routledge.

Benkler, Yochai. 2006. The Wealth of Networks. How Social Production Transforms Markets and Freedom. New Haven: Yale University Press.

Berglund, Eeva. 2008. I Wanted to Be an Academic, Not a 'Creative': Notes on Universities and the New Capitalism. ephemera: theory \& politics in organization 8 (3): 322-330. Accessed 19 January 2018. http://www.ephemerajournal.org/contribution/i-wanted-be-academic-not-creative-notes-universities-and-new-capitalism

Bourdieu, Pierre, ed. 1999. The Weight of the World: Social Suffering in Contemporary Society. Oxford: Polity Press.

Bourdieu, Pierre. 1997. Marginalia-Some Additional Notes on the Gift. In The Logic of the Gift: Toward an Ethic of Generosity, edited by Alan D. Schrift, 231-241. New York: Routledge.

Bourdieu, Pierre. 1986. Distinction: A Social Critique of the Judgement of Taste. London: Routledge. 
Brynjolfsson, Eric and Andre McAfee. 2011. Race Against the Machine: How the Digital Revolution is Accelerating Innovation, Driving Productivity, and Irreversibly Transforming Employment and the Economy. Lexington: Digital Frontier Press.

Cederström, Carl and Peter Fleming. 2012. Dead Man Working. Winchester: Zero Books.

Collins, Randall. 1979. The Credential Society: An Historical Sociology of Education and Stratification. New York: Academic Press.

Colman, Dan. 2013. MOOC Interrupted: Top 10 Reasons Our Readers Didn't Finish a Massive Open Online Course. Accessed November 22, 2017. http://www.openculture.com/2013/04/10 reasons you didnt complete a mooc.html

Couldry, Nick and Angela McRobbie. 2010. The Death of the University, English Style. Culture Machine. Accessed November 22, 2017. https://www.culturemachine.net/index.php/cm/article/view/417/429

Czarniawska, Barbara. 2008. Humiliation: A Standard Organizational Product? Critical Perspectives on Accounting 19 (7): 1034-1053.

De Angelis, Massimo. 2017. Omnia Sunt Communia: On the Commons and the Transformation to Postcapitalism. London: Zed Books.

De Angelis, Massimo. 2007. Measure, Excess and Translation: Some Notes on Cognitive Capitalism. The Commoner 12: 71-78. Accessed 19 January 2018. http://www.commoner.org.uk/12deangelis.pdf

De Angelis, Massimo and David Harvie. 2009. "Cognitive Capitalism" and the Rat Race: How Capital Measures Immaterial Labour in British Universities. Historical Materialism 17 (1): 30-33.

Dean, Jodi. 2014. Communicative Capitalism and Class Struggle. spheres: Journal for Digital Cultures 1: 1-16. Accessed 19 January 2018. http://spheres-journal.org/communicativecapitalism-and-class-struggle

Derrida, Jacques. 1994. Given Time: I. Counterfeit Money. Chicago: University of Chicago Press.

edu-factory collective, ed. 2009. Toward a Global Autonomous University. New York: Autonomedia.

Eisenstein, Charles. 2011. Sacred Economics: Money, Gift, and Society in the Age of Transition. Berkeley: North Altantic Books.

Federici, Silvia and George Caffentzis. 2007. Notes on the Edu-Factory and Cognitive Capitalism. The Commoner 12: 63-70. Accessed 19 January 2018. http://www.commoner.org.uk/12federicicaffentz.pdf

Fisher, Mark. 2009. Capitalist Realism: Is There No Alternative? Winchester: Zero Books.

Ford, Martin. 2016. The Rise of the Robots: Technology and the Threat of Mass Unemployment. London: Oneworld Publications.

Gabriel, Yiannis. 2012. Organizations in a State of Darkness: Towards a Theory of Organizational Miasma. Organization Studies 33 (9): 1137-1152.

Gill, Rosalind. 2010. Breaking the Silence: The Hidden Injuries of the Neoliberal University. In Secrecy and Silence in the Research Process: Feminist Reflections, edited by Róisín Ryan-Flood and Rosalind Gill, 228-244. London: Routledge.

Godelier, Maurice. 1999. The Enigma of the Gift. Chicago: University of Chicago Press.

Gorz, André. 1999. Reclaiming Work: Beyond the Wage-Based Society. Cambridge: Polity.

Graeber, David. 2015. The Utopia of Rules. On Technology, Stupidity, and the Secret Joys of Bureaucracy. London: Melville House.

Graeber, David. 2011. Debt: The First 5,000 Years. London: Melville House.

Gregory, Karen and Joss Winn, eds. 2016. Marx, Engels and the Critique of Academic Labor. Special Issue of Workplace: A Journal for Academic Labor 28.

Grimmelmann, James. 2014. The Merchants of MOOCs. Seton Hall Law Review 44 (4): 1035-1049.

Hall, Richard. 2013. Educational Technology and the Enclosure of Academic Labour Inside Public Higher Education. Journal for Critical Education Policy Studies 11 (3): 52-82. 
Hardin, Garrett. 1968. The Tragedy of the Commons. Science 162: 1243-1248.

Hardt, Michael. 2004. Multitude: War and Democracy in the Age of Empire. London: Penguin Books.

Hardt, Michael. 2000. Empire. Cambridge: Harvard University Press.

Hardt, Michael and Antonio Negri. 2009. Commonwealth. Harvard: Harvard University Press.

Harvie, David. 2006. Value Production and Struggle in the Classroom: Teachers within, against and Beyond Capital. Capital \& Class 30 (1): 1-32.

Holt, John. 1976. Instead of Education: Ways to Help People Do Things Better. New York: Dutton.

Hyde, Lewis. 2007. The Gift: How the Creative Spirit Transforms the World. Edinburgh: Canongate Books.

Illich, Ivan. 1971. Deschooling Society. New York: Harper \& Row.

Marx, Karl. 1959. Economic and Philosophic Manuscripts of 1844. Moscow: Progress Publishers.

Mauss, Marcel. 1954. The Gift: Forms and Functions of Exchange in Archaic Societies. Cohen \& West.

McGettigan, Andrew. 2013. The Great University Gamble: Money, Markets and the Future of Higher Education. London: Pluto Press.

Morrish, Liz. 2017. Why the Audit Culture Made Me Quit. Times Higher Education. Accessed March 2, 2017. https://www.timeshighereducation.com/features/why-audit-culture-mademe-quit

Newfield, Chris. 2008. Unmaking the Public University: The Forty-Year Assault on the Middle Class. Cambridge: Harvard University Press.

Ostrom, Elinor. 1990. Governing the Commons: The Evolution of Institutions for Collective Action. New York: Cambridge University Press.

Poritz, Jonathan and Jonathan Rees. 2016. Education Is Not an App: The Future of University Teaching in the Internet Age. London: Routledge.

Rifkin, Jeremy. 2014. The Zero Marginal Cost Society: The Internet of Things, the Collaborative Commons, and the Eclipse of Capitalism. New York: Palgrave Macmillan.

Rosa, Hartmut. 2016. Resonanz: Eine Soziologie der Weltbeziehung. Frankfurt am Main: Suhrkamp.

Rosa, Hartmut. 2013. Social Acceleration: A New Theory of Modernity. New York: Columbia University Press.

Sahlins, Marshall. 1974. Stone Age Economics. London: Tavistock Publications.

Sennett, Richard. 1998. The Corrosion of Character: The Personal Consequences of Work in the New Capitalism. New York: W. W. Norton \& Company.

Slaughter, Sheila and Gary Rhoades. 2004. Academic Capitalism and the New Economy: Markets, State, and Higher Education. Baltimore: The John Hopkins University Press.

Stiegler, Bernard. 2010. For a New Critique of Political Economy. Cambridge: Polity Press.

Strathern, Marilyn, ed. 2000. Audit Cultures: Anthropological Studies in Accountability, Ethics and the Academy. London: New York.

Suissa, Judith. 2010. Anarchism and Education: A Philosophical Perspective. Oakland: PM Press.

van Mourik Broekman, Pauline, Gary Hall, Ted Byfield, Shaun Hides and Simon Worthington. 2015. Open Education: A Study in Disruption. London: Rowman \& Littlefield.

Weiner, Annette. 1992. Inalienable Possessions: The Paradox of Keeping-While-Giving. Berkeley: University of California Press.

Willis, Paul. 1977. Learning to Labour: How Working Class Kids Get Working Class Jobs. Aldershot: Ashgate.

Winn, Joss. 2012. Open Education: From the Freedom of Things to the Freedom of People. In Towards Teaching in Public: Reshaping the Modern University, edited by Mike Neary, Howard Stevenson and Les Bell, 133-147. London: Continuum. 
Wittel, Andreas. 2013. Counter-Commodification: The Economy of Contribution in the Digital Commons. Culture and Organization 19 (4): 314-331.

\section{About the Author}

Andreas Wittel

Andreas Wittel is a Senior Lecturer at the School of Arts and Humanities, Nottingham Trent University. He is interested in the political economy of digital media, in the intersection of capitalism and the internet, and in the search for alternatives to capital. Recent book: Digital Transitions (2016, Lambert Academic Publishing). 